\title{
Persons with Disabilities: A comparative study between Malaysia, United Kingdom and Philippines
}

\author{
Nadzratun Naim Hammad Azizi ${ }^{1}$, Sharifah Nur Asmaa' Syed Azman ${ }^{1}$, \\ Abdul Mu'iz Abdul Razak ${ }^{1}$ Aisyah Mohd Soberi ${ }^{2}$
}

1 Faculty of Law, Universiti Teknologi MARA, 40450 Shah Alam Selangor, Malaysia

2 Faculty of Law, Universiti Malaya, 50603 Kuala Lumpur, Malaysia

nadzratun@uitm.edu.my, sharifahnurasmaa@uitm.edu.my, abdmuiz@uitm.edu.my, aisyahsoberi@um.edu.my Tel: +60122433995

\begin{abstract}
Discrimination against Persons with Disabilities (PWDs) has been an ongoing concern within the international community. Malaysia has made a significant step forward by ratifying the United Nations Convention on the Rights of Persons with Disabilities, albeit with formal reservations and its own Act. Nevertheless, Malaysia is still under the spotlight for its deficiency in establishing an effective penalty and enforcement mechanism apart from the lack of anti-discriminatory provisions. As such, this comparative paper aims to review the current legislations by filling in the gaps in comparison with that of the Philippines and United Kingdom through proposed and reaffirmed actions.
\end{abstract}

Keywords: Persons with Disabilties; comparative Law ;Persons with Disabilities Act 2008 ; rights

eISSN: 2398-4287 @ 2021. The Authors. Published for AMER ABRA cE-Bs by e-International Publishing House, Ltd., UK. This is an open access article under the CC BYNC-ND license (http://creativecommons.org/licenses/by-nc-nd/4.0). Peer-review under responsibility of AMER (Association of Malaysian Environment-Behaviour Researchers), ABRA (Association of Behavioural Researchers on Asians) and CE-Bs (Centre for Environment-Behaviour Studies), Faculty of Architecture, Planning \& Surveying, Universiti Teknologi MARA, Malaysia.

DOI: https://doi.org/10.21834/ebpj.v6iSI6.3048

\subsection{Introduction}

Based on the 2020 United Nation General Assembly Report of the Special Rapporteur on Extreme Poverty and Human Rights, people with disabilities in Malaysia face discrimination and obstacles that prevent them from being able to participate in society on an equal basis with others. At the early age, associated as receivers of charity and welfare, PWDs have always been the subject of discrimination and social exclusion. However, with the establishment of the United Nations Convention on the Rights of Persons with Disabilities (CRPD) and Optional Protocol in 2006, this has been considered a great milestone for this group of people in which it serves to highlight the importance of PWDs to be treated equally and not being discriminated in the society. The CRPD has also required States parties to undertake systematic, comprehensive revision of their national legislation accordingly considering the Convention to protect the rights of persons with disabilities. As such, the Government has also adopted the Persons with Disabilities Act 2008 (PDA) guided by the National Policy for Persons with Disabilities and the National Plan of Action for Persons with Disabilities. As of the year 2020, only 1.6 per cent of the Malaysian population, or 537,000 people with disabilities, were registered under the welfare department, but the Association of Women with Disabilities (AWD had )estimated the actual figure to be around 4.5 million.

Malaysia in taking active participation has taken an important step to protect the rights of people with disabilities by ratifying the CRPD in 2010 despite having formal reservations to the Convention concerning the prohibition of torture and other ill-treatment (Article 15) and the right to liberty of movement and nationality (Article 18). In other words, this is a declaration limiting the Government's legal application of the principles of non-discrimination and equality. Malaysia has also not placed its ratification towards the Optional Protocol, which allows individual complaints from citizens to the international supervisory committee against non-compliance by the Government.

eISSN: 2398-4287 @ 2021. The Authors. Published for AMER ABRA cE-Bs by e-International Publishing House, Ltd., UK. This is an open access article under the CC BYNC-ND license (http://creativecommons.org/licenses/by-nc-nd/4.0/). Peer-review under responsibility of AMER (Association of Malaysian Environment-Behaviour Researchers), ABRA (Association of Behavioural Researchers on Asians) and cE-Bs (Centre for Environment-Behaviour Studies), Faculty of Architecture, Planning \& Surveying, Universiti Teknologi MARA, Malaysia.

DOI: https://doi.org/10.21834/ebpj.v6iSI6.3048 
At present, Malaysia's Persons with Disabilities Act provides no mechanisms for redress and expressly prohibits legal actions against the Government for violating the rights of persons with disabilities. The PDA, enacted in 2008 was expected to bring positive changes in catering to the needs of PWDs.

Nonetheless, regardless of the existence of the PDA to cater to the rights of the PWDs, the lack of enforcement and penalty mechanisms against parties who violated or breached the rights of PWDs is a grave concern. The PDA has also failed to address provisions on anti-discrimination and anti-harassment besides its lack of remedies mechanism against the Government in instances where the Government has contravened any of its provisions. In any legislation protecting civil rights, there is a need to adopt anti-discrimination measures to show the implementation and enforcement of the rights.

As an example, the PDA is different from Disability Discrimination Act in the United Kingdom as it lacks legal services for PWDs and legal action. For instance, it is not compulsory for the owner of a building to provide access for the disabled. In clause 26(2), Chapter 1 in Part IV in the PDA, it is only mentioned that the Government and provider or owner of service and public building to give "appropriate consideration" and take necessary measures to ensure that such public facilities, amenities, services and buildings and the improvement of the equipment related here to conform to universal design to make it accessible persons with disabilities. Different from Disability Discrimination Act, the PDA serves more of an administrative and enabling policy without legal penalization being stated.

Hence this paper aims to explore the provisions and practices in relation to PWDs across Philippines, the United Kingdom and Malaysia itself with its objectives to propose that the Government will be better positioned to protect and promote the rights of PWDs by imposing effective mechanisms of enforcement through remedial and penalty provisions, These proposed provisions are to be included for the advancement on the protection given such as providing penalties for breach occurred under the Act and establishment of the conciliatory process when complaint being launched regarding disability discrimination. Therefore, a comparative approach by looking at the legislation in the United Kingdom and Philippines in protecting persons with disabilities is essential for the improvement of the laws in this country.

\subsection{Literature Review}

Persons with Disabilities (PWDs) have always been the subject of discrimination and exclusion by society. They are systematically discriminated against and have been excluded in many human activities, including education, employment, accessibility, sport, and cultural activities; considered as sub-humans without being recognized equally as human beings (Tah,2013). On the 13th of December 2006, the first human rights treaty for the 21st century, UNCRPD, was adopted and received reputable outcomes and enthusiasm from the international community. The UNCRPD and Optional Protocol have been considered as a great milestone to achieve equal protection and participation of disabled people in the legal term.

Following this treaty, Malaysia signed the Convention on the 8th of April 2008 and later the 9th of January 2008, the Persons with Disabilities Act 2008 (Act 685) was published in the Gazette on the 24th of January 2008. National disability legislation is long regarded as a prerequisite for an effective national disability policy. It should not only protect the human rights of persons with disabilities but also provide for the true implementation of those rights, aiming at their full integration in society. Nonetheless, law enforcement officials and other employees of the justice system may employ a discriminatory attitude towards people with disabilities, which may serve as a disincentive to using official channels (Omar, 2012). In terms of accessibility, Malaysia plans on dealing with the accessibility issues for PWDs via its 'Pelan Tindakan Orang Kurang Upaya (OKU) 2016-2022' established under The Ministry of Women, Family and Community Development, which highlighted ten strategic thrusts. Nevertheless, according to Zainol, H. et al. (2018), Malaysia is still very much lacking in considering equal accessibilities and facilities for this group of people.

Looking at the position in Malaysia, regardless of the existence of the PDA to cater to the rights of the PWDs, the lack of enforcement and penalty mechanisms against parties who violated or breached the rights of PWDs is a grave concern. The PDA has also failed to address provisions on anti-discrimination and anti-harassment besides its lack of remedies mechanism against the Government in instances where the Government has contravened any of its provisions. In any legislation protecting civil rights, there is a need to adopt anti-discrimination measures to show the implementation and enforcement of the rights (Tah.2013).

Although Malaysia claims to lobby and advocate the rights of the PWDs, the root word 'discriminate 'and the phrase 'to protect PWDs against discrimination' do not distinctively and visibly appear anywhere in the laws and legislations of Malaysia (Suet Leng,2013). According to Yusof (2011), he stated that although Article 24 of CRPD had promoted access to education to all without discrimination, PDA 2008 must serve and abide by international standards to uphold and protect the rights of the PWDs in which the Government had failed to do so. In addition to this, in terms of State immunity as enshrined in Section 41 and 42 of the PDA 2008 will act as a barrier and a shield for any legal proceedings against the Government, and as such, it has become a serious concern to implement the Act effectively in accordance with international standards and laws in other developed countries. The lax compliance, implementation and enforcement within the Act have led it to be labelled as a 'toothless tiger' by advocating for the rights of persons with disabilities in Malaysia.

In comparison with laws on PWDs in the Philippines, the Government has ratified the CRPD in the year 2008 and yet to sign the Optional Protocol. Domestically, the Philippines ' Government has passed Republic Act No. 7277 or known as the Magna Carta for Disabled Persons which was patterned after the Americans with Disabilities Act. The Carta, together with the BP 344 Accessibility Law serves to grant PWDs in the Philippines equality in rights to non-disabled peers and prohibited acts of discrimination in all social activities. Section 44- 46 of the Charter encompasses provisions on penalties and enforcement by the Secretary of Justice. Generally, this Section provides comprehensive measures in dealing with violations of the provisions within the Charter such as fines and summons. Instances of noncompliance are penalized either by imprisonment or payment of fines or both. Some administrative penalties are also imposed, such as revocation of licenses in the case of architects and engineers or cancellation of business permits in the case of business establishments. 
In comparison with another developed common law country, on the 8th of June 2009, the UK Government ratified the Convention signalling its commitment to take concrete action to comply with the legal rights and obligations contained in the Convention. The Government has also ratified the Convention's Optional Protocol which allows its people to petition the UN Committee on the Rights of Persons with Disabilities if they believe that their Convention rights have been breached. They have exhausted means of redress via the UK or European Courts. This step also gives the relevant UN Committee authority to undertake inquiries when reliable information is received into allegations of grave or systematic violations of Convention rights (Butlin,2008).

\subsection{Methodology}

This study employs the traditional doctrinal analysis of the primary sources of law, which includes existing legislation in Malaysia's legal framework that is specifically held to be catering to the issue on PWDs. The relevant statutes for regulating and ensuring the implementation of rights of the PWDs are Persons with Disabilities Act 2008, National Policy for Persons with Disabilities, National Plan of Action for Persons with Disabilities, United Nations Convention on the Rights of Persons with Disabilities (CRPD) and Optional Protocol in 2006. References were also made to the guidelines and circulars released by any organizational bodies regarding the rights of PWDs, as well as domestic circulars (if any) released by the Government and related ministries. Since this study is comparative in nature, crossreference with the legislations in both the Philippines and the United Kingdom are also referred to. In obtaining a clear understanding of the practical aspect of the subject matter, an interview with Rosli lbrahim, who is a prominent activist in this field and the chairman of Mobiliti Massa OKU Bangkit, has been conducted to get in-depth information and to reflect the Government or any organizational body efforts in protecting and upholding the rights of the PWDs.

The first limitation of this study is the lack of time and cost constraint in completing this study. In having a comparative-based research centred within Malaysia, Philippines and the United Kingdom, its findings cannot be generalized to other countries and situations. Other than that, the scope of this paper is confined to review anti-discrimination laws as well as the penalty mechanisms embedded in their legislations and policies in the selected countries. The respondents of the study are also limited in number due to the focused scope of this study which is limited to PWDs.

\subsection{Findings}

\subsection{Laws and National Policies on Persons with Disabilities (PWDs) in Malaysia}

The Government introduced the PWD Act 2008 to bring into domestic law the principles of the UN Convention on the Rights of PWDs (CRPD). From a human rights perspective, the Act marks a small but significant step forward for catering the benefits of PWDs. Albeit the legislations introduced, there have been predicaments and difficulties faced by the PWDs by those who have violated the protection of the disabled provisions under the PWD Act 2008 of which devastatingly, there is nothing that can penalize or remedy the wrongful action as there are no penalty mechanisms that can be imposed on the wrongdoers. The apparent protection of the rights of persons with disabilities under the PWD Act would be illusory without an effective redress mechanism that is accessible by those the Act seeks to protect. The Act provides no compulsion on other Ministries and agencies to comply as well as the absence of provisions in the Act to set up a body or to appoint a person with powers to enquire into alleged breaches of provisions of the Act, including complaints from PWDs of discrimination. Provision for PWDs to seek legal remedies or redress against discrimination in employment, education, public transport, and housing are also not incorporated in the Act. Without any sanctions for non-compliance, it may render the Act less effective. The Act should therefore be amended to ensure better protection of the rights of PWDs. Due to the weaknesses found in the Act, this study seeks to remedy such shortcomings with those domestic laws and national policies that of a developed country, i.e., the United Kingdom and a developing country close to home, i.e., the Philippines, which had successfully incorporated elements that are not found in the PWD Act 2008.

\subsection{Disability Rights in the Philippines}

The Philippines' policy towards persons with disabilities is expressed in national legislation and guidelines adopted by the Government. The Government had undertaken several efforts to make changes to the system to uphold the rights of the PWDs. These efforts were further reinforced with the passage in 1992 of Republic Act No. 7277, also known as the Magna Carta for Disabled Persons, which marked a turning point in the policy and program development for persons with disabilities. Known as the centrepiece of disability legislation of the Philippines, the Magna Carta is comprehensive legislation covering the rights and privileges of persons with disabilities. It has indeed provided persons with disabilities full participation and equalization of opportunities in seven significant areas of concern, which are, in areas of employment, education, health services, auxiliary social services, telecommunication, accessibility in transportation and communication, and recognition of their political rights.

The Carta was promulgated to promote the common good of the differently abled persons, giving those incentives and privileges in the world of education, employment, training, and self-preservation and/or broadening their self-esteem. The law also prohibits the public from discriminating against the differently abled persons, or otherwise, those who exercise such will be given penalties such as imprisonment. Thus, this law was specifically designed for the full enjoyment and recreation of the differently abled persons. To further promote the welfare of the differently abled persons, a Revision of the Republic Act 7277 was considered to promote the life of differently abled people further. The new sections, 32 and 33, were added to issue more incentives and privileges for disabled persons. The Government of the Philippines sees to it that the implementation of Republic Act 9442 shall be met accordingly. Because of this, they 
added fines or penalties and even imprisonment to be charged to any person or institution that does not appropriately follow the provision stated in the law. In return, this makes every individual and institution observe proper treatment to any differently able persons.

\subsection{Disability Rights in the United Kingdom}

In the United Kingdom, there is the Disability Discrimination Act (DDA) 1995 and the recently implemented Equality Act 2010 that oblige all employers to make the necessary adjustments to the employment arrangements as well as work for the disabled, require the public sector to promote disability equality and prohibit discriminatory practices against PWDs and their parents. Becoming law in October 2010, the Equality Act 2010 replaces the existing anti-discrimination laws with a single Act. It simplifies the law, removing inconsistencies and making it easier for people to understand and comply with it. It also strengthens the law in significant ways to help tackle discrimination and inequality. The Equality Act not only harmonizes and unifies all the existing strands of anti-discrimination legislation but also introduces new provisions to strengthen protections against discriminatory and stigmatizing practices, inside and outside the workplace. If a person with a disability feels they have been discriminated against, they may want to take their case to a Tribunal. If they win the case, they may be able to claim for financial loss and damages for injuries to feelings.

\subsection{Comparison between Malaysia, United Kingdom and the Philippines}

Having gone through the salient features incorporated in the provisions of the domestic legislation in the UK and the Philippines, particularly in the scope of the enforcement and penalty mechanism, it is best to see the comparison between the former countries and Malaysia as stated in Table 1 below.

Table 1. Comparison of Laws on PWDs between Malaysia, United Kingdom and the Philippines.

\begin{tabular}{|c|c|c|c|}
\hline Criteria & Malaysia & United Kingdom & Philippines \\
\hline Laws on PWDs & $\begin{array}{l}\text { Persons with } \\
\text { Disabilities Act } 2008\end{array}$ & $\begin{array}{l}\text { Disability } \\
\text { Discrimination Act } \\
1995 \text { (former) } \\
\text { Disability } \\
\text { Discrimination Act } \\
2005 \text { (former) } \\
\text { Equality Act } 2010\end{array}$ & $\begin{array}{l}\text { Magna Carta for } \\
\text { Disabled Persons } \\
\text { (Republic Act No, } \\
\text { 7277) } \\
\text { Revision to the RA } \\
\text { 7277: RA } 9442\end{array}$ \\
\hline Definition of PWDs & $\begin{array}{l}\text { Section } 2 \text { of PWD } \\
\text { Act } 2008\end{array}$ & $\begin{array}{l}\text { Section } 6 \text { of EA } \\
2010\end{array}$ & $\begin{array}{l}\text { Section } 4 \text { of Magna } \\
\text { Carta }\end{array}$ \\
\hline Wellbeing of PWDs & $\begin{array}{l}\text { Part IV of PWD Act } \\
\text { Promotion and } \\
\text { Development of the } \\
\text { Quality of Life and } \\
\text { Wellbeing of PWDs }\end{array}$ & $\begin{array}{l}\text { Section } 20 \text { of EA } \\
2010 \\
\text { Duty to make } \\
\text { Adjustments }\end{array}$ & $\begin{array}{l}\text { Chapter } 8 \text { of RA } \\
9442 \\
\text { Privileges and } \\
\text { Incentives }\end{array}$ \\
\hline Monitor Implementation Mechanism & $\begin{array}{l}\text { National Council for } \\
\text { Persons with } \\
\text { Disabilities } \\
\text { Section } 9 \text { of the } \\
\text { PWD Act. Functions } \\
\text { of the Council in } \\
\text { overseeing the } \\
\text { overall } \\
\text { implementation } \\
\text { make } \\
\text { recommendation, } \\
\text { and review any } \\
\text { policies and national } \\
\text { plan related with } \\
\text { persons with } \\
\text { disabilities. }\end{array}$ & $\begin{array}{l}\text { Section 207- } \\
\text { Exercise of Power } \\
\text { to make an order } \\
\text { or regulations } \\
\text { under this Act is } \\
\text { exercisable by a } \\
\text { Minister of the } \\
\text { Crown. }\end{array}$ & $\begin{array}{l}\text { National Council on } \\
\text { Disability Affairs } \\
\text { (NCDA) } \\
\text { (Formerly National } \\
\text { Council for the } \\
\text { Welfare of Disabled } \\
\text { Persons or NCWDP) } \\
\text { Section } 11 \text { of } \\
\text { Magna Carta } \\
\text { Promulgate the } \\
\text { rules and } \\
\text { regulations } \\
\text { necessary to } \\
\text { implement the } \\
\text { provisions under } \\
\text { the Act as well as to } \\
\text { monitor the } \\
\text { implementation of } \\
\text { several laws to } \\
\text { ensure the } \\
\text { protection of the } \\
\text { PWDs civil and } \\
\text { political rights. }\end{array}$ \\
\hline Enforcement/Penalty Mechanism & $\begin{array}{l}\text { Not available - } \\
\text { Only the existence } \\
\text { of } \\
\text { Section } 41 \text { and } 42 \text { of } \\
\text { the PWD Act } 2008\end{array}$ & $\begin{array}{l}\text { Part } 9 \text { of EA } 2010 . \\
\text { Section } 119\end{array}$ & $\begin{array}{l}\text { Section } 46 \\
\text { Penal Clause }\end{array}$ \\
\hline $\begin{array}{l}\text { Legal Action on Compliancy } \\
\text { Ratification of CRPD }\end{array}$ & Not Available & $\begin{array}{l}\text { Available } \\
\text { The } 8^{\text {th }} \text { of June } 2009\end{array}$ & Available \\
\hline
\end{tabular}




\begin{tabular}{|c|c|c|c|}
\hline Ratification on Optional Protocol & $\begin{array}{l}\text { The } 19^{\text {th }} \text { of July } \\
2010\end{array}$ & $\begin{array}{l}\text { The } 7^{\text {th }} \text { of August } \\
2009\end{array}$ & $\begin{array}{l}\text { The } 15^{\text {th }} \text { of April } \\
2008\end{array}$ \\
\hline Reservations & - & None & - \\
\hline Types of Discrimination as stated under the law & $\begin{array}{l}\text { Article } 15 \text { and Article } \\
18 \\
\text { Not Available }\end{array}$ & $\begin{array}{l}\text { Section } 13 \text { - Direct } \\
\text { Discrimination } \\
\text { Section } 15- \\
\text { Discrimination } \\
\text { arising from } \\
\text { Disability } \\
\text { Section } 19 \text { - } \\
\text { Indirect } \\
\text { Discrimination } \\
\text { Harassment } \\
\text { Victimization } \\
\text { Discrimination by } \\
\text { Association } \\
\text { Perceptive } \\
\text { Discrimination }\end{array}$ & $\begin{array}{l}\text { Section } 32 \text { - } \\
\text { Discrimination on } \\
\text { Employment } \\
\text { Section } 34 \text { - } \\
\text { Discrimination on } \\
\text { Transportation } \\
\text { Section } 35 \text { - } \\
\text { Discrimination on } \\
\text { the Use of Public } \\
\text { Accommodations \& } \\
\text { Services }\end{array}$ \\
\hline
\end{tabular}

Back home in Malaysia, as previously stated, the government had taken a huge step when ratifying the CRPD and further enacted its own domestic legislation namely the PWD Act 2008. However, even with such efforts made, after several years of the birth of the PWD Act 2008, Malaysia has not fully reached the same level or at par with other developed nations such as the United Kingdom or even a developing nation like the Philippines.

The PWD 2008 defines disability as "those who have long term physical, mental, intellectual or sensory impairments which in interaction with various barriers may hinder their full and effective participation in society". However, this definition is not extensive to encompass the real meaning of the PWDs. A clearer definition is needed so that people will be able to easily understand and respect the true meaning of the act. Definition of PWDs should be extended to other forms of discrimination that may occur for people with disabilities and for it to be addressed in a clearer and detailed manner. In the Equality Act 2010 in the UK, it can be seen that the definition of disability is so comprehensive and thorough so as to ensure that the definition covers all forms of disability experienced by people with disabilities. The shortage as mentioned previously does not mean that there is a need for another legislation act to support the PWD 2008. In the view of most researchers, they are of the opinion that it is not desirable to set up more supplementary legislation as it will cause a lot of confusion and power redundancy. It can clearly be seen with the establishment of the Equality Act 2010 which was created for the purpose of bringing together all the relevant laws on disabled people in the UK. The purpose of the amalgamation under the Equality Act 2010 is to facilitate and avoid any overlapping jurisdictions as well for the betterment of understanding of the society. Having gone through the Equality Act 2010 in the UK, it comprehensively covers disability discrimination wherein it stated that any complaints can be filed to the tribunal appointed under the act or civil court. For example, Section 116 has been allocated for the disabled persons who feel that they have been discriminated against; to lodge a complaint of any discriminatory practice in the education sector to be filed first at tribunal. Similar approach also applied to the case of employment discrimination under Section 120 of EA 2010.

On the other hand, the Philippines laws on PWDs are not that far fetched from the laws in the UK. The definition of the PWDs are expressly provided in Section 4 of the Magna Carta (RA 7277) which is wide enough to include persons who may not traditionally be regarded as disabled but also took the initiative to define PWDs as those who have restrictions or different abilities. The Magna Carta has also paved the way for the implementation of the concept of inclusion since it provides the PWDs full participation and the equalization of opportunities in seven major areas of concern as stated therein. One of the main concerns with regards to this research is on the aspect of the implementation of law in which the Department of Justice is mandated and authorized to ensure that those who violate the law shall be adequately penalized. The Magna Carta has established a penalty mechanism as stated under Section 46 which is also inclusive of penalty for mocking PWDs. Having an insight of the domestic laws and national policies regarding PWDs in Philippines, particularly the Magna Carta (RA 7277), it truly serves as a comprehensive legislation covering the rights and privileges of the PWDs to health, employment, education, auxiliary social services, accessibility, telecommunications as well as political and civil rights. What is very interesting to note is that it also identifies the appropriate departments or agencies of Government to carry out the provisions as enlisted under the Act. This also includes the role of the Department of Justice in carrying out the provisions on enforcement and penalties.

\subsection{Discussion}

The Malaysian Government had taken a considerable step when ratifying the CRPD and further enacted its domestic legislation, namely the PWD Act 2008. However, even with such efforts made, after several years of the birth of the PWD Act 2008, there have been few reported cases of PWDs being discriminated and ill-treated highlighted in the media and newspapers of which such little effort has been made to really curb the problem and solve the ongoing crisis faced by this group of minorities. The Government is still stagnant and not moving forward to indeed pay attention to the PWDs and issues encountered by them. Despite all the international treaties and agreements signed by Malaysia, the Government has failed, in fact, to incorporate the provisions into the current domestic legislation. 
Looking at Malaysia's legislation on PWDs, overall, the PWD 2008 focuses mainly on the aspect of recognition of the rights of the disabled. However, the absence of punishment for anyone who violates these provisions under the Act makes it impossible and unbearable to treat the Act with seriousness and to make a significant impact on its use further. This protection is merely a pretentious form of security without an effective enforcement mechanism. The absence of any provisions relating to any form of punishment for those who violate the provisions of this Act had also caused the Act to be less known and had faced a lack of attention from the public.

An Act that lacks enforcement and an effective penalization system for violators does not outweigh the legal system. There is nothing that can be done for those who had deliberately or undeliberately violated the Act. As such, the main aim to uphold the rights of the PWDs has failed to be realized. Therefore, a form of punishment should be established to ensure that this legislation is to be respected and followed. It must be noted that real change can only be achieved if the Government or the victims of the violations of the Act can describe, identify and report human rights violations against the perpetrator. It is only through a proper channel or mechanism and support from the Government by way of an established legal system this can be achieved.

\subsection{Conclusion \& Recommendations}

Firstly, it is hoped that upon completion of this study, several suggestions will be made for additional studies that need to be conducted based on the results of this research. Secondly, it is strongly proposed that Malaysia should retract all the reservations made to the CRPD as well as to finally incorporate the penalty mechanism as well as anti-discriminatory laws in our legislation by following the example of the United Kingdom and Philippines. Lastly, it is also hoped that this study will provide useful directions for new researchers and readers who are interested in exploring further research on this subject matter.The finding reveals that Malaysia must take further action to ensure that the PWD Act 2008 has a more effective mechanism for the enforcement of rights under the provisions. Any delay in seeking to introduce penalties and fines in the Act to any person who violates any part under the Act would further dampen the effort to realize the Act's enforcement mechanism.

\section{References}

Coupland, R, "Humanity: What Is It And How Does It Influence International Law?" Revue Internationale de la Croix-Rouge/International Review of the Red Cross 83(844): 969-989, 2011

Davis, Bernard et al, "Unification, Simplification, Amplification? An Analysis Of Aspects Of The British Equality Act 2010." Commonwealth Law Bulletin 38(3): 509-528, 2012.

Easton, C., "Revisiting The Law On Website Accessibility In The Light Of The Uk's Equality Act 2010 And The United Nations Convention On The Rights Of Persons With Disabilities." International Journal of Law and Information Technology 20(1): 19-47, 2012.

Faridah Serajul Haq, "Career And Employment Opportunities For Women With Disabilities In Malaysia." Asia Pacific Disability Rehabilitation Journal 14(1): 71-78, 2003.

Furuoka, F., et al, "Employment Situation of Person with Disabilities: Case Studies of US, Japan and Malaysia." Journal of Arts, Science \& Commerce, 2 (4): 1-10. 2011.

Ikmal Hisham Md Tah, "A Need For Remedial Provision To Protect Persons With Disabilities In Malaysia." International Journal of Business, Economics and Law, Vol. 3 , Issue 3 (December) ISSN 2289-1552, 2013

Ikmal Hisham Md Tah, "Orang Kurang Upaya (OKU) dan Hak untuk Hidup: Satu Analisis Perundangan di Malaysia", International Journal of Business, Economics and Law, Vol. 3, Issue 3 (December) ISSN 2289-1552, 2013

Ikmal Hisham Md. Tah , "Rights of Persons with Disabilities: The "Almost Forgotten"Protection under the Federal Constitution", in Khairil Azmin Mokhtar (Ed.),Constitutional Law \& Human Rights in Malaysia: Topical Issues and Perspectives(pp. 411-430), 2013.

Jamil R, Saidin S. Employment of Persons with Disabilities (PWDs) in Malaysia: Moving Policy Rhetoric into Action. Asian Journal of Management Cases. 2018;15(2_suppl):S1-S16. doi:10.1177/0972820118804967

Jani, R., Alias, A. A., \& Tumin, M. (2020). Persons with disabilities' education and quality of life: Evidence from malaysia. International Journal of Inclusive Education

Jayasooria, Denison, Krishnan Bathmavathi and Godfrey Ooi, "Disabled People In A Newly Industrialising Economy: Opportunities And Challenges In Malaysia." Disability \& Society 12(3): 455-463, 1997.

Kanter, A. S, "The Promise and Challenge of the United Nations Convention on the rights of Persons with Disabilities" Syracuse J. Int'l L. \& Com. 34: 287. 2006)

Kwan, F., 2020. 2020 e-census lacks views from persons with disabilities, says group. Free Malaysia Today, Available at: <htps://www.freemalaysiatoday.com/category/nation/2020/10/06/2020-e-census-lacks-views-from-persons-with-disabilities-says-group/> [Accessed 4 November 2021]

M. Rezaul Islam,"Rights of the People with Disabilities and Social Exclusion in Malaysia."International Journal of Social Science and Humanity 5(2): 171-177, 2015.

Mah Hassan Omar, Persons With Disabilities Act Of Malaysia - Challenges In Implementation, 15th DPIAP Regional Assembly, 2012

Mepham, S. "Disabled Children: The Right To Feel Safe." Child care in practice 16(1): 19-34, 2010.

Mina, C. D, "Employment of Persons with Disabilities (PWDs) in the Philippines: The Case of Metro Manila and Rosario, Batangas", 2013. 
Mohammad Faizal Che Yusof, "Akta Orang Kurang Upaya 2008, Harapan Dan Realiti: Satu Pendekatan Praktikal", Praxis July-September 2011.

Moore, Allen and Sarah Kornblet, Advancing the Rights of Persons with Disabilities: A US-Iran Dialogue on Law, Policy and Advocacy, < http://www.stimson.org/books reports/advancing-the-rights-of-persons-with-disabilities-a-us-iran-dialogue-on-law-policy and-advocacy/>.

Nasir, M.N.A (2020), The Socio-Economic Situation of Disabled Persons in Malaysia, International Journal of Business, Economics and Law, Vol. 23, Issue 1 (December) ISSN 2289-1552

Nasir, M.N.A., \& Efendi, A.N.A.E. (2020). "If you don't fall into a drain, you can't graduate!": Disabled Malaysians in higher education sector. International Journal for Studies on Children, Women, Elderly and Disabled People, 10, 44-53.

Quinn, G, "The United Nations Convention on the Rights of Persons with Disabilities: Toward a New International Politics of Disability" (Texas Journal on Civil Liberties \& Civil Rights, Volume 15:1, 2009)

Rohana Jani, Abd Aziz Alias \& Makmor Tumin (2020) Persons with disabilities' education and quality of life: evidence from Malaysia, International Journal of Inclusive Education, DOI: 10.1080/13603116.2020.1726511

Sarah Fraser Butlin,"The UN Convention on the Rights of Persons with Disabilities: Does the Equality Act 2010 Measure up to UK International Commitments?" , Industrial Law Journal. 2011.

Schulze, M, "Understanding the UN Convention on the Rights of Persons with Disabilities." New York, NY: Handicap International. Retrieved the 21st of March: $2012,2010$.

Suet Leng Khoo, Ling Ta Tiun and Lay Wah Lee, "Unseen Challenges, Unheard Voices,Unspoken Desires: Experiences Of Employment By Malaysians With Physical Disabilities." Kajian Malaysia 31(1): 37, 2013.

Tan,C, Abdullah, M.N \& Shuib, M. (2019). Policies and practices governing disability in Malaysia's higher education: A comparison with England and Australia, Journal of International and Comparative Education, 2019, Vol. 8, Issue 2 ISSN 2232-1802

Thwaites, L, "The British Equality Framework is Incapable of Achieving Equality in the Workforce" NEL Rev. 2: $137,2014$.

Tiun Ling Ta and Khoo Suet Leng, "Challenges Faced by Malaysians with Disabilities in the World of Employment." Disability, CBR \& Inclusive Development 24(1): 6-21,2013

UNGA, Report of the Special Rapporteur on Extreme Poverty and Human Rights, 2020.

Zainol, H., et al. (2018). "Social Sustainable Accessibility for People with Disabilities at Public Transport Stations through Sustainable Development Goals in Malaysia." Environment-Behaviour Proceedings Journal 3. 